\title{
Pelatihan Manajemen Transportasi Dalam Upaya Menciptakan Efisiensi Tata Kelola Jaringan Trayek Dan Sumber Daya Manusia Pada Masyarakat Di Kawasan Pantura Kabupaten Lamongan
}

\author{
Zulkifli Lubis, Randi Bactiar Afandi, Emalia Nova Sustyorini \\ Program Megister Manajemen, Universitas Islam Lamongan, Indonesia \\ Email corresponding authors:zulkiflilubis@unisla.ac.id
}

\begin{abstract}
ABSTRAK
Kegiatan pengabdian masyarakat ini bertujuan untuk mendeskripsikan pelayanan angkutan umum, tingkat efesiensi penggunaan angkutan umum, Jaringan Trayek angkutan umum di Kecamatan Paciran dan Kecamatan Brondong. Fokus pelaksanaan ini pada masyarakat di Kecamatan Lamongan, Babat, Paciran dan Brondong yang dapat menggunakan transportasi massal dengan cepat dan aman. Lokasi Pelaksanaan ini meliputi Paciran dan Brondong. Sumber data menggunakan data primer dan data sekunder. Teknik pengumpulan data dilakukan dengan cara menggunakan studi literatur dan studi lapangan. Teknik analisis data menggunakan deskriptif kualitatif dan kuantitatif. Hasil pengamatan di Wilayah pusat kota di kedua kota tersebut memiliki tingkat kepadatan yang relatif tinggi, namun laju pertumbuhan penduduk di pusat Kota Lamongan masih bertambah walaupun memiliki tingkat kepadatan yang jauh lebih tinggi, Trayek cabang kecamatan yang dilayani oleh armada jenis MPU cenderung tidak berkembang, Hal ini menunjukkan bahwa permintaan angkutan umum di Kabupaten Lamongan relative tidak menyebar. Efesiensi penggunaan angkutan umum di kecamatan Lamongan, Kecamatan Babat, Kecamatan Paciran dan Kecamatan Brondong sudah memenuhi standard. Jaringan trayek angkutan umum cabang kecamatan yang dilayani oleh armada jenis MPU cenderung tidak berkembang, Hal ini menunjukkan bahwa permintaan angkutan umum di Kabupaten Lamongan relative tidak menyebar. Trayek ranting dikedua kota tersebut tidak dapat disamakan, karena keduanya memiliki zona pelayanan yang berbeda.
\end{abstract}

Kata Kunci : Sumber Daya Manusia, Transfortasi.

\section{PENDAHULUAN}

Pembangunan perekonomian di Indonesia sangat membutuhkan jasa angkutan yang cukup memadai. Transportasi sebagai sarana penunjang aktivitas kegiatan, memberikan peran penting dalam mencapai tujuan pengembangan ekonomi di Kabupaten Lamongan. Sebagaimana tujuan pembangunan ekonomi di Indonesia secara umum adalah:

1) Menciptakan pendapatan nasional yang disertai distribusi secara merata antara penduduk, bidang-bidang usaha dan daerah-daerah.

2) Meningkatkan jenis dan jumlah barang jadi dan jasa yang dapat dihasilkan para konsumen, industri dan pemerintah.

3) Mengembangkan industri nasional yang dapat menghasilkan devisa, serta men-supply pasaran dalam negeri.

4) Menciptakan dan memelihara tingkatan kesempatan kerja bagi masyarakat (Salim, 2003).

Seiring dengan perkembangan perekonomian maka berkembang pula aktivitas masyarakat yang meningkatkan pertumbuhan suatu kota. Pertumbuhan suatu kota ditandai dengan munculnya beberapa kawasan permukiman baru, kawasan industri, perdagangan dan jasa (komersial). Pertumbuhan suatu kota yang di dalamnya melibatkan aktivitas penduduk menyebabkan peningkatan terhadap kebutuhan sarana transportasi (angkutan) dalam rangka melakukan pergerakan. Fenomena penumpukan lalulintas pada jam - jam puncak sudah 
menjadi problem transportasi perkotaan saat ini. Sehingga masalah transportasi ini menjadi sangat penting untuk dianalisis karena setiap tahun.

Penduduk semakin bertambah dan pemukiman didaerah pinggiran makin menjamur dan makin padat. Rute angkutan yang tidak sampai didaerah pinggiran mengakibatkan masalah pada sisi supply, pelayanan angkutan umum perkotaan tidak merata sampai ketitik pemukiman yang ada didaerah pinggiran (Sub urban). Indikasi tersebut tercermin dari fenomena penggunaan kendaraan pribadi diwilayah pinggiran yang masih cukup tinggi. Sekitar 50\% penduduk pinggiran di Kabupaten Lamongan masih bekerja dipusat kota, dan sekitar 50\% jarak perjalanan mereka tiap hari lebih dari $10 \mathrm{~km}$. Akan tetapi jarak ini tidak menjadi masalah karena dengan menggunakan kendaraan pribadi biaya transportasi cenderung lebih murah. Hal ini sebetulnya membuat permasalahan kemacetan (Ismiyati, 2005). Sedangkan menurut Lyon (2001) angkutan umum dibutuhkan untuk memberikan derajat fleksibilitas yang tinggi untuk menyaingi secara efektif mobil pribadi atau diistilahkan dengan mobilitas personal (perorangan).

Kebijakan adanya angkutan umum di daerah Kecamatan Brondong, Kecamatan Paciran dan Kecamatan Babat dapat dimungkinkan sebagai solusi alternatif pilihan masyarakat melakukan pergerakan. Kebutuhan angkutan umum pada suatu wilayah tentunya tidak sama. Karakteristik wilayah dan pergerakan masyarakat menjadi salah satu faktor penentu keberadaan angkutan umum jenis tertentu.

Angkutan umum jenis angkutan kota yang merupakan alat angkut mobil dengan kapasitas sedang layak dijalankan pada wilayah kota yang saling berdekatan, sedangkan angkutan umum tipe minibus lebih baik untuk wilayah antar kota yang jaraknya lebih dari 10 $\mathrm{Km}$ dengan kapasitas lebih banyak dan melewati rute jalan raya/ propinsi.

Keberadaan angkutan kota belum ditemui di Kecamatan Paciran dan Kecamatan Brondong. Sementara itu angkutan umum yang cukup memenuhi untuk kebutuhan masyarakat memang tersedia, namun demikian yang memenuhi keinginan khalayak terutama sisi kecepatan dan kenyamanan pada sarana transportasi masih dirasa kurang. keberadaan angkutan umum dalam suatu wilayah tidak mengalami persebaran secara merata. Pada akhirnya ada sebagian wilayah yang tidak terlayani oleh keberadaan angkutan umum.

Fenomena tersebut terjadi karena minimnya tingkat pelayanan terhadap kebutuhan angkutan umum terutama dari kenyaman, kecepatan dan keamanan serta keselamatan penumpang. Kondisi tersebut menyebabkan tumbuhnya aktivitas angkutan kurang diminati oleh pengguna transportasi umum dan lebih memilih ojek atau becak. Penggunaan becak dan ojek memang tingkat aksesibilatsnya tinggi, akan tetapi biaya yang dikeluarkan konsumen lebih mahal. Peranan angkutan kota/minibus sebagai pengisi (gap-filler) kebutuhan angkutan di suatu daerah. Kebijakan pemerintah mengembangkan angkutan umum secara masal perlu dilakukan pengkajian lebih lanjut guna memberikan pelayanan pada masyarakat daerah.

Kecamatan Brondong merupakan bagian wilayah Kabupaten Lamongan yang terletak disebelah utara. Batas wilayah utara yaitu laut jawa, selatan kecamatan laren dan solokuro, bagian barat tuban serta bagian timur paciran, Lamongan. Angkutan umum yang ada diwilayah ini diantaranya Colt MPU ke tuban, Dokar/kereta kuda serta becak.

Kecamatan paciran ada di Wilayah Kabupaten Lamongan yang berada di belahan Utara Ibu Kota Kabupaten Lamongan dengan jarak +43 Km. yang terdiri dari 16 Desa 1 Kelurahan , 34 Dusun, 95 RW, 379 RT. Luas Wilayah Kecamatan Paciran 61,304 Km² terletak pada ketinggian $2 \mathrm{M}$ di atas permukaan air laut. Jumlah Penduduk di Wilayah Kecamatan Paciran sebanyak : 90.604 Jiwa terdiri dari Laki-laki : 45.514 Jiwa, Perempuan : 45.090 Jiwa 
dan 24.869 KK, yang tersebar di 17 ( Tujuh Belas ) Desa / Kelurahan. Di Kecamatan Paciran terdapat Jalan Poros Desa sepanjang 20.610 M yang menghubungkan Desa satu dengan Desa yang lain. Jalan Poros Desa yang dibangun dari Dana JAPORDES dan ADD sepanjang $14.048 \mathrm{M}$ dalam kondisi baik, sedangkan sisanya sepanjang $6.562 \mathrm{M}$ sangat diperlukan perhatian khusus untuk mendapatkan bantuan baik dari APBD Kabupaten Lamongan, Propinsi maupun dari Pemerintah Pusat

Kecamatan, Paciran dan Brondong merupakan wilayah dengan tingkat pertumbuhan dan perkembangan relatif maju, yang dilalui oleh jalan lokal primer sebagai penghubung antara Kecamatan Brondong dan Kecamatan Paciran serta Kecamatan Babat dan Kecamatan Lamongan yang merupakan pusat pelayanan dan aktivitas di Kabupaten Lamongan bagian tengah dan utara. dengan moda transportasi yang melayani pergerakan penduduk dari daerah pinggiran ke pusat kota diharapkan dapat memberikan peningkatan.

Pelayanan angkutan umum yang mampu memberikan kemudahan aksesibilitas pergerakan masyarakat secara komprehensip dari lokasi pinggiran sampai ke kota sehingga dapat menunjang roda perekonemian, serta mengatasi permasalahan kemacetan pada jam tertentu. Sistem pembatasan jumlah angkutan dan rute yang jelas dimungkinkan menekan peningkatan supply jumlah angkutan yang berlebihan (over capacity of service) dan akses masyarakat terlayani dengan baik sehingga permintaan masyarakat akaa angkutan umum meningkat dan terdapat peningkatan pendapatan pengusaha angkutan umum.

\section{METODE PELAKSANAAN}

Jenis pelaksanaan yang diambil adalah termasuk jenis applied research yang bertujuan untuk memberikan masukan terkait dengan transportasi massal di Kecamatan Paciran dan Brondong. Analisis metodologi yang digunakan adalah analisis kuantitatif yaitu untuk menjelaskan dan menganalisis secara mendalam sarana transportasi berdasarkan Undang-Undang Nomor 22 Tahun 2009 tentang lalu lintas dan angkutan jalan. Pelaksanaan ini menggunakan obyek pada transpostasi massal yang ada di Paciran dan Brondong. Fokus pelaksanaan ini pada masyarakat Paciran dan Brondong dapat menggunakan transportasi massal dengan cepat dan aman. Lokasi Pelaksanaan ini adalah Kabupaten Lamongan meliputi Kecamatan Paciran dan Brondong. Sumber data menggunakan data primer dan data sekunder. Teknik pengumpulan data dilakukan dengan cara menggunakan studi literatur dan studi lapangan. Teknik analisis data menggunakan deskriptif kualitatif dan kuantitatif.

\section{HASIL DAN PEMBAHASAN}

\section{1) Penentuan Wilayah Pelayanan}

Berdasarkan pada pedoman praktis dan keterangan yang dapat digunakan dalam menentukan wilayah pelayanan angkutan penumpang umum bila proses perencanaan dapat dilaksanakan. Penentuan titik terjauh permintaan pelayanan angkutan penumpang umum didaerah Paciran - Brondong dapat dihitung sebagai berikut:

a) Kecamatan Paciran - Brondong

Jumlah Permintaan pelayanan angkutan umum yang terletak disekitar batas wilayah kecamatan dapat dihitung sebagai berikut:

Jumlah Penduduk : $61.802+90.604=152.406$

Penduduk melakukan pergerakan dengan asumsi 50\%: 76.203 


$$
\mathrm{K}=\frac{3000}{76.203}
$$

Diperoleh angka pemilihan kendaraan pribadi 0.04

Jumlah penumpang yang diangkut oleh kendaraan pribadi 6.097

Diperoleh kemampuan pelayanan kendaraan pribadi 0.04

Jumlah kemampuan potensial melakukan pergerakan yang melakukan pergerakan dan membutuhkan pelayanan angkutan umum penumpang sama dengan selisih antara jumlah penduduk potensial melakukan pergerakan dan kemampun pelayanan kendaraan pribadi untuk penduduk tersebut Sehingga dapat dihitung:

Angka pemilihan kendaraan pribadi:

$$
\mathrm{V}={ }^{3000} \times \overline{46} \quad \mathrm{x} 0.04
$$

L Pelayanan 0.04. $76.203-6.097$

$\mathrm{L}=2.804$

Dapat disimpulkan pelayanan kendaraan pribadi yang dapat dilayani sebesar 2.804 penduduk

Sehingga dari total penduduk yang melakukan pergerakan sebesar

$76.203-2.804=73.399$ penduduk

\section{2) Indikator Kuantitatif}

\section{a) Aksesabilitas}

Aksesabilitas angkutan umum dikawasan paciran dapat terlihat dari dua parameter yaitu jarak tempuh dan waktu tunggu. Jarak tempuh yang baik adalah jarak pendek dalam mencapai angkutan umum, sedangkan waktu tunggu untuk mendapatakan angkutan umum tergolong kurang baik pada jam - jam tertentu dikarenakan jumlah armada yang sedikit, sehingga pengguna angkutan umum cenderung khawatir tidak mendapatkan angkutan umum terutama pada jam tertentu misalkan sore hari.

\section{b) Kapasitas}

Berdasarkan hasil survey dan analisis maka didapatkan jumlah penumpang yang dapat ditampung perhari perkendaraan adalah sebesar 240 penumpang dengan nilai ideal untuk kapasitas angkutan umum jenis MPU adalah sebesar 250 - 300 penumpang perhari perkendaraan. Untuk mendapatkan jumlah armada pada jam sibuk sebagai berikut:

CT ABA $:(18+18)+(0.92+0.92)+(8)=46$ Menit 18

$$
\mathrm{K}=\text {-------- } 120=47 \text { Kendaraan }
$$

Maka dapat disimpulkan bahwa jumlah kendaraan yang dibutuhkan untuk jalur paciran sebesar 47 kendaraan dari total kendaraan yang tersedia 18 unit. 


\section{3) Indikator Kuantitatif}

a) Aksesabilitas

Aksesabilitas angkutan umum dikawasan paciran dapat terlihat dari dua parameter yaitu jarak tempuh dan waktu tunggu. Jarak tempuh yang baik adalah jarak pendek dalam mencapai angkutan umum, sedangkan waktu tunggu untuk mendapatakan angkutan umum tergolong kurang baik pada jam - jam tertentu dikarenakan jumlah armada yang sedikit, sehingga pengguna angkutan umum cenderung khawatir tidak mendapatkan angkutan umum terutama pada jam tertentu misalkan sore hari.

b) Kapasitas

Berdasarkan hasil survey dan analisis maka didapatkan jumlah penumpang yang dapat ditampung perhari perkendaraan adalah sebesar 240 penumpang dengan nilai ideal untuk kapasitas angkutan umum jenis MPU adalah sebesar 250 - 300 penumpang perhari perkendaraan. Untuk mendapatkan jumlah armada pada jam sibuk sebagai berikut:

CT ABA $:(18+18)+(0.92+0.92)+(8)=46$ Menit

$$
\mathrm{K}=\frac{84}{46} 120=219 \text { Kendaraan }
$$

Maka dapat disimpulkan bahwa jumlah kendaraan yang dibutuhkan untuk jalur paciran sebesar 219 kendaraan dari total kendaraan yang tersedia 84 unit. Karakteristik pelayanan rute angkutan umum, hasil observasi dilapangan menemukan bahwa: tujuan utama pergerakan masih tertuju dilayanan potensial yaitu kantor, pasar dan sekolah serta sebanyak $25 \%$ pergerakan menuju kepusat kota.

Analisis data menunjukkan rata - rata jalur yang ditempuh angkutan umum pada masing - masing kecamatan sekitar 15 - 18 menit sampai tempat tujuan. Hasil analisis kuantitatif menunjukkan bahwa masing - masing jalur yang terbebani angkutan umum membutuhan tambahan armada sebagai berkut :

\begin{tabular}{lccc}
\hline Wilayah & Total Armada & Kesediaan & Kurang \\
\hline Paciran - Brondong & 47 & 18 & 29 \\
\hline
\end{tabular}

\section{4) Pelayanan Angkutan Umum dengan Manajemen Kebutuhan Transportasi}

Kabupaten Lamongan merupakan kota daerah tingkat II yang sarana infrastruktur masih banyak kelemahan, akan tetapi kenyataan yang harus dihadapi laju kebutuhan transportasi harus mampu ditapung oleh sistem prasarana transportasi. Sebab usaha peningkatan kualitas dan kuantitas pelayanan sistem prasarana transportasi pada suatu daerah tertentu dapat meningkatkan aksesabilitas dan mobilitas didaerah tersebut, dan sebaliknya akan dapat merangsang kembali terjadinya peningkatan kebutuhan transportasi.

Pergerakan dan gaya hidup masyarakat Kabupaten Lamongan serta di tunjang dengan peningkatan penghasilan menyebabkan kebutuhan transportasi dan sistem prasarana transportasi yang saling kejar mengejar dan tidak akan pernah berhenti sampai kondisi jenuh tercapai ( macet total). Bukti yang jelas terlihat pembangunan jalan yang telah mengeluarkan dana sangat besar dalam usaha peningkatan kualitas dan kuantitas sistem prasarana transportasi cukup tinggi, akan tetapi kemacetan, pengaturan 
lalu lintas dengan tingkat intensitas dan kompleksitas yang tidak berubah dan bahkan semakin parah.

Usaha pemecahan permasalahan transportasi perkotaan pada saat sekarang adalah usaha meningkatkan kualitas dan kuantitas sistem prasarana transportasi yang ada sama saja. Karena lambat laun akan terjadi kemacetan juga dengan tingkat intensitas yang lebih parah. Selama pemerintah daerah kabupaten Lamongan bersedia mengkoordinir dana anggaran untuk dialokasikan ke infrastruktur, tidak jadi masalah yang berarti pada manajemen transportasi. Akan tetapi pemerintah memerlukan dana yang relatif besar untuk memperbaiki pelayanan jasa sistem prasarana transportasi perkotaan yang merupakan pendukung utama bagi perbaikan kondisi ekonomi.

Pendekatan konvensional masih perlu dilakukan oleh para perencana transportasi dan para pengambil keputusan adalah dengan mengakomodasikan setiap pertumbuhan kebutuhan transportasi dalam bentuk peningkatan kapasitas dan efesiensi prasarana serta jaringan. Hal ini dilakukan dengan pembangunan prasarana baru, peningkatan kapasitas pranasarana yang sudah ada, dan peningkatan efesiensi penggunaan prasarana dengan berbagai perangkat kebijakan rekayasa dan manejemen lalulintas yang sudah ada. Pendekatan ini dirasakan sangat efektif untuk jangkah waktu pendek saja, sejalan dengan peningkatan kebutuhan pergerakan yang sangat cepat., pendekatan ini dirasakan tidak akan efesien lagi dan sangat sulit dilaksanakan apabila dilihat dari kebutuhan dana yang sangat besar.

\section{5) Beberapa Kebijakan Penopang konsep manajemen kebutuhan transportasi}

Tidak ada satupun kebijakan (single solution) yang dapat langsung memecahkan secara tuntas masalah transportasi perkotaan. Kebijakan yang diambil harus merupakan gabungan dari beberapa kebijakan atau strategi yang secara sinergi akan dapat memecahkan masalah transportasi yang ada. Untuk itu perlu ada kebijakan lain:

\section{6) Kebijakan peningkatan kapasitas prasarana}

Kebijakan ini harus dilaksanakan secara sangat selektif tergantung dari tingkat prioritas dan kemampuan pendanaan. Hal ini disebabkan karena selain membutuhkan biaya yang sangat besar juga akan dapat berdampak negative berupa terjadinya peningkatan pergerakan melalui peningkatan aksesabilitas dan mobilitas peningkatan prasarana dapat dilakukan selain melebarkan jalan, juga dapat dilakukan dengan memperbaiki titik - titik rawan kemacetan yang banyak terdapat pada jaringan jalan dan sistem hirarki serta pembangunan jalan terobosan baru harus dilakukan sesegera mungkin untuk menghindari penyempitanPelebaran dan perbaikan geometrik persimpangan Pembuatan persimpangan tidak senbidang. Pembangunan jalan terobosan baru untuk melengkapi sistem jaringan jalan yang telah ada dan pembenahan sistem hirarki jalan. Hal ini terutama terlihat pada daerah yang berbatasan dengan daerah administrasi lain. Karena tidak ada koordinasi yang baik antara kedua pemerintah daerah, maka pembangunan sistem jaringan jalan didaerah perbatasan sering tidak sinkron sehingga menimbulkan penyempitan. Pembuatan jembatan penyeberangan baik untuk pejalan kaki maupun untuk kendaraan pada daerah tertentu untuk mengurangi kecelakaan dan juga untuk membuka isolasi akibat pembangunan jalan lingkar atau terobosan yang memisahkan satu daerah menjadi dua daerah yang terisolasi. 


\section{7) Kebijakan Rekayasa dan Manajemen Lalulintas}

Kebijakan rekayasa dan manajemen lalu lintas dapat diberlakukan dengan berbagai cara, yaitu:

a. Pemasangan dan perbaiakan sistem lampu lalulintas baik secara terisolasi maupun terkoordinasi yang dapat mengikuti fluktuasi arus lalulintas. Pengaturan ini akan dapat mengurangi tundaan dan kemacetan.

b. Perbaikan Perencaan sistem jaringan jalan yang ada, termasuk jaringan jalan Kereta Api, jalan raya, bus, dilaksanakan untuk menunjang sistem angkutan Umum Transportasi.

c. Perlunya penerapan pembatasan lalu lintaslalulintas ( traffic restraint) terhadap kendaraan pribadi telah diterima oleh para pakar transportasi.

\section{Hal Lain Yang dapat Dilakukan}

a. Pelatihan Transportasi Perkotaan bagi staf pemerintah daerah.

Kesiapan pemerintah daerah dalam mengelola dan mengatur daerahnya sendiri sangatlah penting dan diperlukan beberapa kajian menyimpulkan bahwa banyaknya permasalahan transportasi dikota bukan hanya disebabkan oleh factor kurangnya jumlah prasarana dan fasilitas transportasi, tapi kadang ketidaksiapan SDM dalam mengelola. Oleh karena itu pelatihan merupakan cara yang sangat efektif untuk memperluas wawasan dan pengetahuan aparat dan staf pemerintah daerah dalam masalah transportasi, termasuk mengelola, merencana dan mengatur.

\section{b. Sosialisasi peraturan dan penegakan hukum.}

Ketidaksiplinan selalu merupakan alas an utama terjadinya permasalahan transportasi perkotaan. Bagaimanapun baiknya sistem perlalulintasan, jika tidak dibarengi dengan disiplin berlalulintas yang baik, akan tetap menimbulkan masalah, selain itu disiplin tidaknya pengguna jalan tidak saja bergantung pada dirinya sendiri, tetapi juga pada ketegasan sistem perlalulintasan yang berlaku, termasuk undang - undang dan peraturan, penegakan hukum, sosialisasi hukum, sarana dan prasarana.

\section{KESIMPULAN DAN SARAN}

Kinerja pelayanan angkutan umum Di jalur kecamatan utara kabupaten Lamongan berkaitan dengan perbedaan struktur kota adalah sebagai berikut:

1. Wilayah pusat kota di kedua kota tersebut memiliki tingkat kepadatan yang relatif tinggi, namun laju pertumbuhan penduduk di pusat Kota Lamongan masih bertambah walaupun memiliki tingkat kepadatan yang jauh lebih tinggi,

2. Efesiensi penggunaan angkutan umum di Kecamatan Paciran dan Kecamatan Brondong sudah memenuhi standard.

3. Trayek cabang kecamatan yang dilayani oleh armada jenis MPU cenderung tidak berkembang, Hal ini menunjukkan bahwa permintaan angkutan umum di Kabupaten Lamongan relative tidak menyebar. Trayek ranting dikedua kota tersebut tidak dapat disamakan, karena keduanya memiliki zona pelayanan yang berbeda. 


\section{DAFTAR PUSTAKA}

Abbas Salim (1998), Manajemen Transportasi, Penerbit PT Raja Grafindo Persada. Jakarta; Asikin, M.Z., 2001, Sistem Manajemen Transportasi Kota, Philosophy Press Fakulta Filsafat Universitas Gajah Mada, Yogyakarta.

Bambang Pudjianto (2002), Bahan Kuliah Sistem Angkutan Umum dan Barang, PPs MTS Konsentrasi Transportasi UNDIP, Semarang

Black, (1981) Perencanaan dan teknik lalulintas, gajah mada university press, yogjakarta. 